\title{
Morphological Changes Induced by Insulin-Like Growth Factor-I Gene Therapy in Pituitary Cell Populations in Experimental Prolactinomas
}

\author{
Gisela A. Camihort ${ }^{a}$ Claudia B. Hereñú ${ }^{b}$ Georgina C. Lunac Silvia S. Rodríguez \\ María I. Bracamonte ${ }^{a}$ Rodolfo G. Goyab Gloria M. Cónsole ${ }^{a, c}$ \\ ${ }^{a}$ Department of Cytology, Histology and Embryology B, ${ }^{b}$ INIBIOLP, Faculty of Medicine, National University of \\ La Plata, and ${ }^{\mathrm{C}} \mathrm{CICPBA}$, La Plata, Argentina
}

\section{Key Words}

Insulin-like growth factor type I - Prolactinomas $\cdot$ Pituitary

cell populations $\cdot$ Gene therapy $\cdot$ Estrogen $\cdot$ Rat

\begin{abstract}
In previous studies, we assessed the effects of intrapituitary injection of a recombinant adenoviral vector (RAd) harboring the CDNA for rat insulin-like growth factor type I (RAdIGF-I) on the lactotrope and somatotrope populations in estrogen-induced prolactinomas. In the present study, we aimed to confirm these findings and further analyze the effect of transgenic RAd-IGF-I on the other pituitary cell popu-
\end{abstract}

lations in female rats. All animals except the intact group (no estrogen and no stereotaxic injection) received subcutaneous estrogen for 30 days, and the groups which received RAd-IGF-I or RAd expressing green fluorescent protein (control) were additionally treated with the appropriate vectors on experimental day 0 . The RAd-IGF-I group showed a significant decrease in serum growth hormone and prolactin levels and lactotrope and somatotrope cell size induced by estrogen treatment. Cell density was not affected by 7 days of IGF-I gene therapy. Estrogen had an inhibitory effect on thyrotrope cell density, whereas with RAd-IGF-I there was a nonsignificant trend towards restoration of cell density, without changes in cell size. RAd-IGF-I treatment decreased

\section{Abbreviations used in this paper}

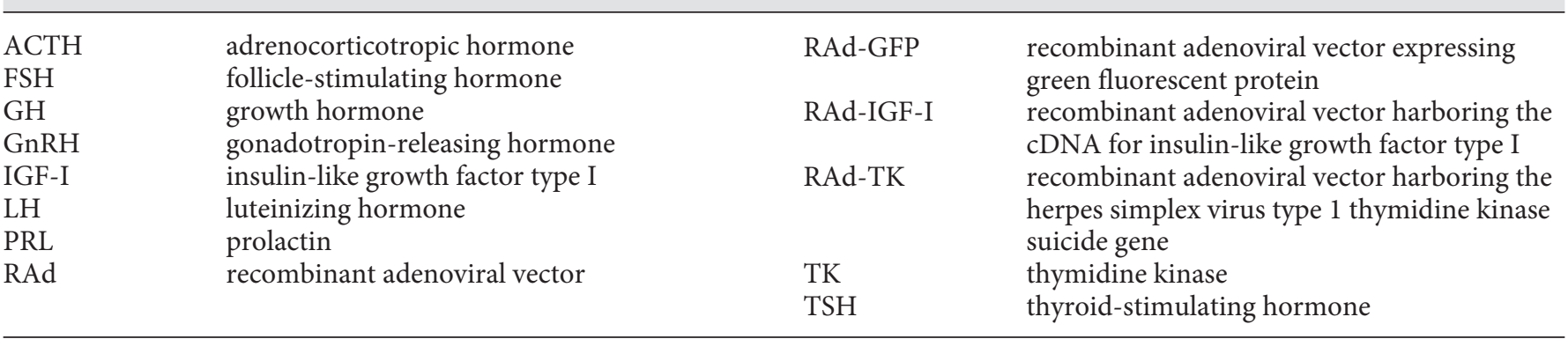

\section{KARGER}

Fax +4161306 1234 E-Mail karger@karger.ch www.karger.com 
corticotrope cell size without changing cell density. Estrogen decreased gonadotrope cell size and density, which was reversed by RAd-IGF-I. We conclude that in estrogen-induced pituitary tumors, IGF-I gene therapy has inhibitory effects on the lactotrope, somatotrope and corticotrope populations, while reversing the effect of estrogen on gonadotropic cells.

Copyright $\odot 2009$ S. Karger AG, Basel

\section{Introduction}

Insulin-like growth factor I (IGF-I) is abundant and homogeneously distributed throughout the anterior and intermediate pituitary lobes [D'Ercole et al., 1984]. Although this is compatible with its expression by endocrine cells, IGF-I mRNA was detected in cells scattered throughout the gland which showed features typical of nonendocrine folliculostellate cells [Bach and Bondy, 1992]. The pituitary gland contains several growth factors [Webster et al., 1989; Halper et al., 1992] that may affect the function and proliferation of pituitary cells through autocrine or paracrine actions [Houben and Denef, 1994]. Stimulation of sensory neurons prevents apoptosis by increasing IGF-I in various tissues [Okajima and Harada, 2008].

Estrogens have been shown to rapidly induce lactotrope cell tumors within 2-4 weeks in female rats. Estrogen exposure has been linked to the formation of prolactinomas in both humans and animals [Sarkar et al., 1982; Lloyd, 1983]. Women taking oral contraceptives often display increased prolactin (PRL) levels and have an increased incidence of prolactinomas, although not all women appear to be equally susceptible to the mitogenic effect of estradiol [Shy et al., 1983].

Although estrogen is known to upregulate IGF-I mRNA in normal rat pituitaries [Michels et al., 1993], large estrogen-induced pituitary adenomas have been reported to possess decreased levels of IGF-I mRNA. Furthermore, partial remission induced by the antiestrogen tamoxifen was associated with an increase in the pituitary content of IGF-I mRNA in such adenomas [Hána et al., 1998]. It has also been shown that in primary cultures of rat lactotropes, estrogen has an antiproliferative action in the presence of insulin or IGF-I [Kawashima et al., 2002; Ishida et al., 2007].

We have recently demonstrated that in vivo delivery of the gene for rat IGF-I in estrogen-induced rat prolactinomas was able to partially reverse hyperprolactinemia and restore lactotrope [Cónsole et al., 2008] and somatotrope cell morphology [Cónsole et al., 2009]. In the present study, we expanded our investigations into the actions of IGF-I gene therapy in estrogen-induced pituitary tumors by assessing the effect of this treatment on other endocrine pituitary cell populations in these tumors.

\section{Materials and Methods}

\section{Adenoviral Vectors}

A recombinant adenoviral vector (RAd) harboring the rat IGF-I gene (RAd-IGF-I; IGF-I gene kindly donated by Dr. Peter Rotwein, Oregon Health Sciences University) was constructed in our laboratory by a variant of the 2-plasmid method employing the $\operatorname{AdMax}^{\circledR}$ plasmid kit (Microbix, Ontario, Canada) [Hereñú et al., 2007]. Briefly, the cDNA coding for the rat IGF-I gene (obtained from the mRNA for the IGF-Ib precursor form) [Daughaday and Rotwein, 1989] was excised from the plasmid pBluescript $\mathrm{KS}$, subcloned in pCA14 and inserted into the multiple cloning site of shuttle pDC515, which contains an expression cassette consisting of the mouse cytomegalovirus promoter and the simian virus 40 polyadenylation signal, immediately upstream and downstream, respectively, of the multiple cloning site. The second plasmid from the kit, the genomic plasmid pBHGfrt(del)E1,3 FLP, consists of the entire genome of adenovirus 5, with deletions in the regions E1 and E3. In cotransfected HEK293 cells, FLP recombinase is readily expressed and efficiently catalyzes the site-directed recombination of the expression cassette of pDC515 into pBHGfrt(del)E1,3 FLP, thus generating the genome of the desired vector RAd-IGF-I. The newly generated RAd was rescued from HEK293 cell lysates and plaque purified. It was further purified by ultracentrifugation in $\mathrm{CsCl}$ gradient. Final virus stocks were titrated by a serial-dilution plaque assay.

Another adenoviral vector was constructed in our laboratory following the general procedures outlined above and was used as a control vector in the gene therapy studies. The vector harbors a hybrid gene encoding the Aequorea victoria enhanced green fluorescent protein (EGF) fused to herpes simplex virus type 1 thymidine kinase (TK) (a kind gift from Dr. Jacques Galipeau, McGill University, Montreal, Canada). This hybrid gene is driven by the mouse cytomegalovirus promoter. The vector (named RAd-GFP) was expanded in HEK293 cells and purified and titrated as for the RAd-IGF-I vector.

\section{Animals}

Young female Sprague-Dawley rats were housed in a temperature-controlled room $\left(22 \pm 2^{\circ} \mathrm{C}\right)$ on a 12/12-hour light/dark cycle. Food and water were available ad libitum. All experiments with animals were performed according to the Animal Welfare Guidelines of the National Institutes of Health (INIBIOLP's Animal Welfare Assurance No. A5647-01).

\section{Experimental Design for in vivo IGF-I Gene Therapy}

On experimental day -30 , all animals but those of the intact group (no estrogen and no stereotaxic injection) were subcutaneously implanted with Silastic capsules filled with $17 \beta$-estradiol. Small blood samples $(0.4 \mathrm{ml})$ were taken from the tail veins of all rats on experimental days $-25,-15,-10,0$ and +7 for PRL/growth 
hormone (GH) assays. On experimental day 0 , some of the rats received bilateral $1.5-\mu$ l intrapituitary injections containing $3 \times$ $10^{9}$ plaque-forming units of either RAd-GFP or RAd-IGF-I. For this purpose, rats were anesthetized with an injection of ketamine hydrochloride (40 mg/kg, i.p.) and xylazine ( $8 \mathrm{mg} / \mathrm{kg}$, i.m.) and placed in a stereotaxic frame. In order to access the pituitary region, the tip of a 26 -gauge needle fitted to a 10 - $\mu$ l syringe was inserted to the following coordinates relative to the bregma: 5.5 $\mathrm{mm}$ posterior, $9.6 \mathrm{~mm}$ ventral and $0.7 \mathrm{~mm}$ right and left [Paxinos and Watson, 1998]. One week after intrapituitary injection, rats were killed by decapitation. Pituitaries were immediately dissected, fixed and processed for routine histological studies.

\section{Immunohistochemistry}

The immunohistochemical procedure was documented previously [Cónsole et al., 2001]. In brief, pituitary tissues from 5 animals of each group were fixed in Bouin's fluid and embedded in paraffin. Serial sections of $4 \mu \mathrm{m}$ were obtained at different levels of the blocks following a ventral-to-dorsal sequence. The sections were immunostained and then incubated for $1 \mathrm{~h}$ at room temperature with the primary antibodies anti-GH, -PRL, -TSH, -adrenocorticotropic hormone $(\mathrm{ACTH})$, -follicle-stimulating hormone (FSH) and -luteinizing hormone (LH) (murine, Dako, Calif., USA), diluted 1:100. Thoroughly washed sections were then treated for 30 min with a ready-to-use Envision reaction system (Dako). The peroxide-sensitive chromogen was diaminobenzidine. In all instances, the specificity of the primary antiserum was monitored either by observing its ability to block the immunocytochemical reaction after preabsorption with an excess of the related antigen or by its replacement with normal rabbit serum or phosphate-buffered saline.

\section{Image Analysis}

Morphometry was performed as reported in detail previously [Cónsole et al., 2002]. In brief, measurements of immunostained pituitary cells were performed by means of an image analysis system (Imaging Technology, Optimas 5.2). The cells and reference area were analyzed in each field on an average of 10 micrographs taken from 2 levels. These measurements were recorded and processed automatically, and the following parameters were subsequently calculated: cell density (number of cells/reference area) and cell size (expressed in square micrometers). The reference area represents the total area throughout which the cells were scored. The number of cells (cell density) was calculated by dividing the immunostained area of the pituitary tissue by the mean individual cell area. For this parameter, 100 cells were recorded in each field.

\section{Hormone Assays}

Serum levels of GH and PRL were measured by a specific radioimmunoassay using rat materials provided by Dr. A.F. Parlow (Pituitary Hormones and Antisera Center, UCLA Medical Center, USA). Iodination grade hormones were radiolabeled by the Iodo-Gen ${ }^{\circledR}$ method and purified on PD-10 Sephadex ${ }^{\circledR}$ G-25 M columns (Pharmacia, Uppsala, Sweden) equilibrated with $0.01 \mathrm{M}$ phosphosaline (pH 7.6). A $1 / 10$ goat antirabbit IgG in $0.9 \% \mathrm{NaCl}$ was used to separate bound from free hormone. Serum concentrations of GH and PRL were expressed in terms of NHPP rGHRP-2 and rPRL-RP-3.
Statistical Analysis

Analysis of variance was used to evaluate group differences. Tukey's method was chosen as a post hoc test.

\section{Results}

Effect of IGF-I Gene Therapy on Pituitary Morphology

The estrogen treatment induced a significant increase in pituitary size (data not shown). The impact of intrapituitary injection of RAd-IGF-I on the endocrine cell populations of the adenomas was already evident when immunohistochemically stained pituitary sections were qualitatively assessed (fig. 1, 2).

Morphometric assessment revealed that the lactotrope population underwent a significant $(\mathrm{p}<0.01)$ increase in cell density in rats that received estrogen but no vector compared to the intact animals $(32.5 \pm 2$ vs. $19.1 \pm 3)$. Seven days of RAd-IGF-I gene therapy did not affect lactotrope cell density in estrogen-treated animals compared to animals treated with RAd-GFP $(31.6 \pm 1.1 \mathrm{vs}$. $33.8 \pm 3)$, but pituitary adenomas in estrogen-treated animals showed a significant $(\mathrm{p}<0.01)$ increase in lactotrope cell size as compared with their intact counterparts $\left(60.1 \pm 1.5\right.$ vs. $\left.39.4 \pm 0.5 \mu \mathrm{m}^{2}\right)$. Seven days of IGF-I gene therapy significantly $(\mathrm{p}<0.01)$ reversed this change $[43.2$ $\pm 0.5 \mu \mathrm{m}^{2}$ (estrogen + RAd-IGF-I) vs. $59.2 \pm 1.5 \mu \mathrm{m}^{2}$ (estrogen + RAd-GFP)] (fig. 3).

In quantitative terms, morphometric analysis revealed that the somatotrope cells in estrogen-treated rats without stereotaxic injections showed a significant $(\mathrm{p}<0.01)$ increase in cell size as compared with intact controls (59.9 \pm 1.1 vs. $\left.40.6 \pm 1.3 \mu \mathrm{m}^{2}\right)$ and had a significant $(\mathrm{p}<0.01)$ decrease in cell density compared to intact animals (9.6 \pm 0.1 vs. $18.2 \pm 1.5$ ). Treatment of pituitary adenomas with RAd-IGF-I induced a significant $(\mathrm{p}<0.05)$ decrease in cell size compared to estrogen + RAd-GFP treatment $\left(53.5 \pm 1.3\right.$ vs. $\left.59.6 \pm 1.2 \mu \mathrm{m}^{2}\right)$, but no changes were detected in cell density as compared with RAd-GFP-injected animals $(11.3 \pm 0.7$ vs. $10.1 \pm 0.1$; fig. 3$)$.

The thyrotrope population in rats treated with estrogen without stereotaxic injection did not show significant changes in TSH cell size $\left(72.7 \pm 2.7\right.$ vs. $\left.76.3 \pm 0.7 \mu \mathrm{m}^{2}\right)$ but showed a significant $(\mathrm{p}<0.01)$ decrease in cell density compared to intact animals $(0.3 \pm 0.1$ vs. $3.1 \pm 0.2)$. Treatment of pituitary adenomas with RAd-IGF-I induced a nonsignificant increase in TSH cell density (0.5 \pm 0.1 vs. $0.3 \pm 0.1)$ without changes in TSH cell size ( 67.5 \pm 3.8 vs. $70.4 \pm 1.9 \mu \mathrm{m}^{2}$ ) compared to treatment with RAd-GFP (fig. 3). 


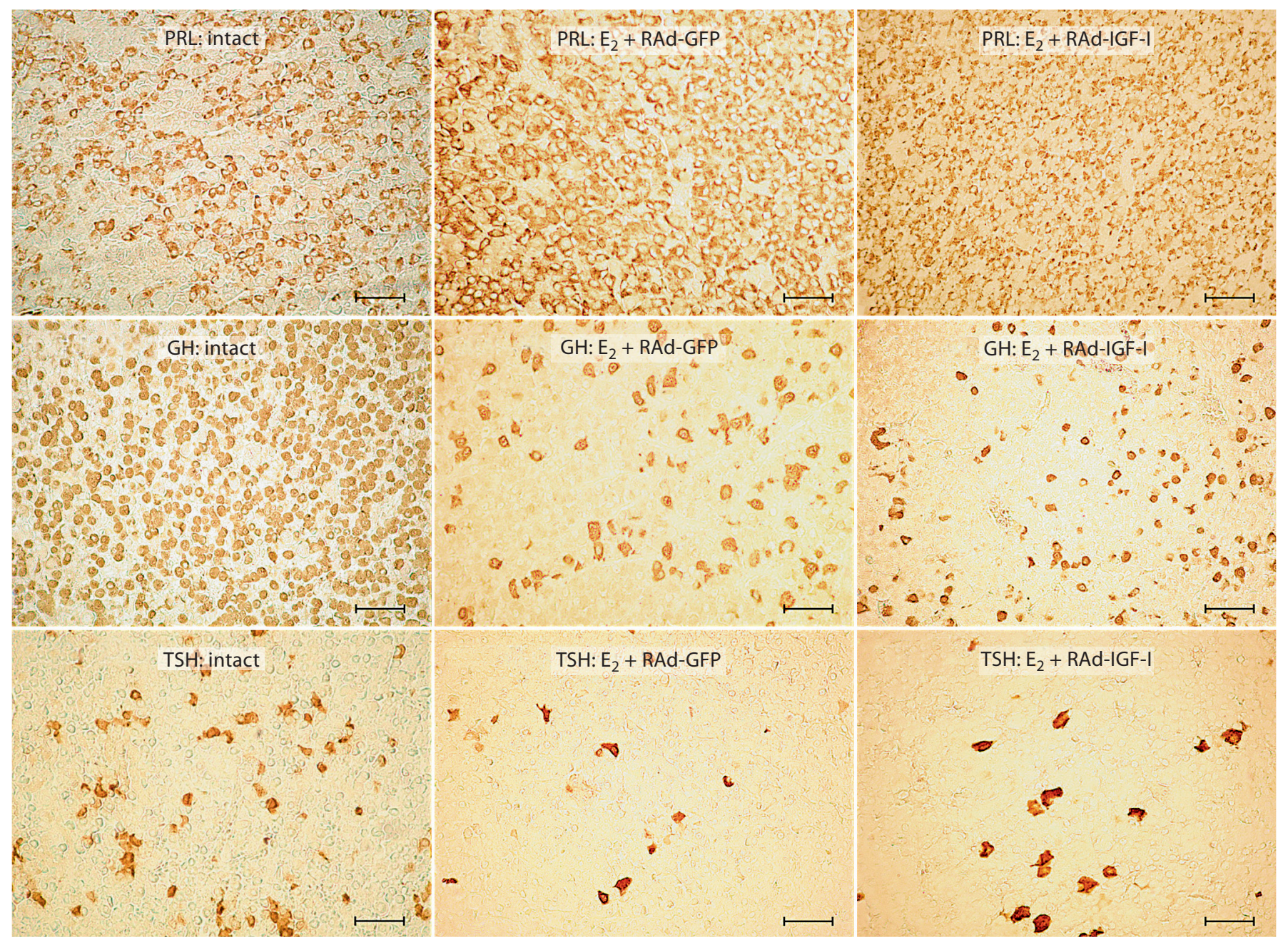

Fig. 1. Effect of IGF-I gene therapy on PRL, GH and TSH cell populations of pituitary adenomas. Representative fields of specifically immunostained cells from the pituitary gland of an intact rat, an animal which received estrogen for 4 weeks and RAd-GFP during the last experimental week ( $E_{2}+$ RAd-GFP) and an animal which received estrogen for 4 weeks and RAd-IGF-I during the last experimental week $\left(\mathrm{E}_{2}+\mathrm{RAd}-\mathrm{IGF}-\mathrm{I}\right)$. Envision system peroxidase. $\mathrm{Bar}=45 \mu \mathrm{m}$.

The corticotrope population underwent a significant $(p<0.01)$ decrease in cell density in rats treated with estrogen without stereotaxic injection $(1.9 \pm 0.1$ vs. $3.2 \pm$ $0.1)$ but did not show any changes in cell size ( $47 \pm 2.3$ vs. $51.3 \pm 0.6 \mu \mathrm{m}^{2}$ ) compared to intact animals. Treatment of pituitary adenomas with RAd-IGF-I induced a significant $(\mathrm{p}<0.05)$ decrease in ACTH cell size $(38.6 \pm 2$ vs. $46.5 \pm 1 \mu \mathrm{m}^{2}$ ), but no changes were detected in cell density compared to Rad-GFP ( $1.8 \pm 0.1$ vs. $2 \pm 0.1$; fig. 4$)$.

Morphometric analysis revealed that the gonadotrope cells immunostained by anti-FSH antibody in rats treated with estrogen without stereotaxic injection presented a significant $(\mathrm{p}<0.01)$ decrease in cell size $(62.4 \pm 1.6$ vs. $\left.88 \pm 0.1 \mu \mathrm{m}^{2}\right)$ and cell density $(0.9 \pm 0.1$ vs. $4.1 \pm 0.2)$ as compared with intact controls. RAd-IGF-I induced a significant $(\mathrm{p}<0.01)$ increase in cell size $(85 \pm 3.4$ vs. 61.4 $\left.\pm 1.5 \mu \mathrm{m}^{2}\right)$ and cell density $(1.7 \pm 0.2$ vs. $0.9 \pm 0.1 ; \mathrm{p}<$ $0.01)$ as compared with RAd-GFP-injected animals (fig. 4).

The gonadotrope cells immunostained by anti-LH antibody in rats treated with estrogen without stereotaxic injection showed a significant $(\mathrm{p}<0.05)$ decrease in cell size $\left(69.6 \pm 0.4\right.$ vs. $\left.79 \pm 1.7 \mu \mathrm{m}^{2}\right)$ and cell density $(3.1 \pm$ 0.1 vs. $6.2 \pm 0.1 ; \mathrm{p}<0.01)$ as compared with intact controls. RAd-IGF-I induced a significant $(\mathrm{p}<0.01)$ increase in cell size $\left(90.7 \pm 1.6\right.$ vs. $\left.70.4 \pm 1.7 \mu \mathrm{m}^{2}\right)$ and cell den- 


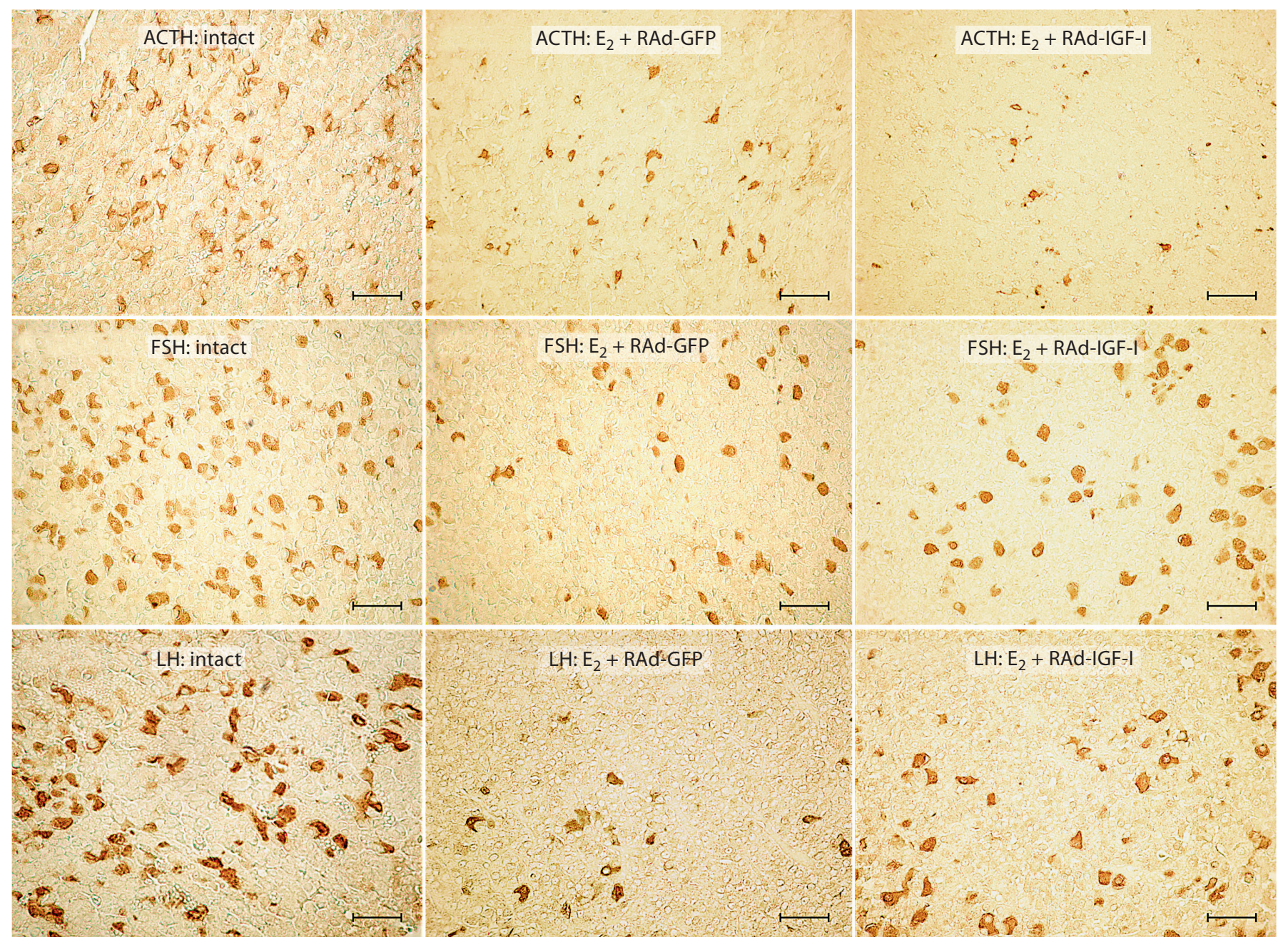

Fig. 2. Effect of IGF-I gene therapy on ACTH, FSH and LH cell populations of pituitary adenomas. Representative fields of specifically immunostained cells in the pituitary gland of an intact rat, an animal which received estrogen for 4 weeks and RAd-GFP during the last experimental week ( $E_{2}+$ RAd-GFP) and an animal which received estrogen for 4 weeks and RAd-IGF-I during the last experimental week $\left(\mathrm{E}_{2}+\mathrm{RAd}-\mathrm{IGF}-\mathrm{I}\right)$. Envision system peroxidase. $\mathrm{Bar}=45 \mu \mathrm{m}$.

sity $(4.5 \pm 0.1$ vs. $3.2 \pm 0.1 ; p<0.05)$ as compared with RAd-GFP-injected animals (fig. 4).

\section{Effect of Chronic Estrogen and Intrapituitary Tumor}

IGF-I Gene Therapy on Serum PRL and GH Levels

Estrogen administration induced marked hyperprolactinemia in the carrier animals. Seven days after stereotaxic intrapituitary injection of RAd-IGF-I but not RAd-GFP, a significant $(\mathrm{p}<0.01)$ fall in serum PRL occurred in the estrogen-treated rats $(138 \pm 22$ vs. $260 \pm$ $57 \mathrm{ng} / \mathrm{ml}$ ). Nevertheless, serum PRL in the RAd-IGF-Itreated rats remained higher than in the intact rats (table 1).
Serum GH was higher $(\mathrm{p}<0.01)$ in estrogen-treated rats versus intact controls $(141 \pm 14 \mathrm{vs.} 24 \pm 7 \mathrm{ng} / \mathrm{ml})$ at 7 days. In rats carrying estrogen-induced adenomas, RAd-IGF-I injection induced a significant $(p<0.05)$ reduction in serum GH with respect to RAd-GFP-injected animals (95 \pm 8 vs. $140 \pm 10 \mathrm{ng} / \mathrm{ml}$; table 2$)$.

\section{Discussion}

Although important advances have been made in the treatment of pituitary tumors with surgery and radiotherapy as well as pharmacological approaches, a fully 

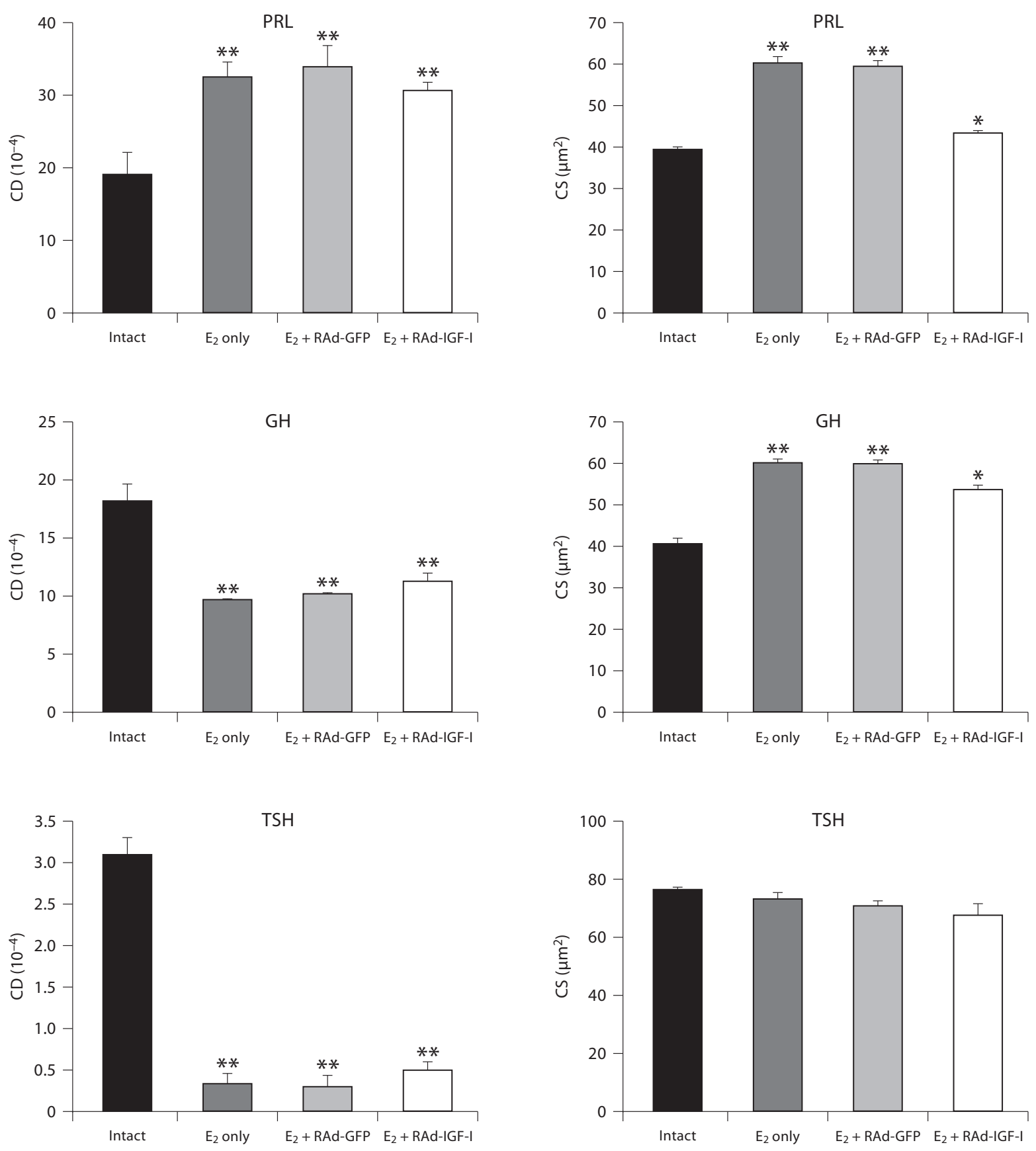

Fig. 3. Effect of IGF-I gene therapy on cell density (CD) and cell size (CS) of lactotropes (PRL cells), somatotropes (GH cells) and thyrotropes (TSH cells) in the pituitaries of an intact animal and animals treated with estrogen only ( $\mathrm{E}_{2}$ only) or estrogen plus RAd-GFP ( $\left.\mathrm{E}_{2}+\mathrm{RAd}-\mathrm{GFP}\right)$ (control treatments) or IGF-I gene therapy ( $\left.\mathrm{E}_{2}+\mathrm{RAd}-\mathrm{IGF}-\mathrm{I}\right)$. Columns represent mean values and bars above columns represent SEM values. Five pituitaries per group were assessed. ${ }^{*} \mathrm{p}<0.05,{ }^{* *} \mathrm{p}<0.01$ compared to the intact group. 

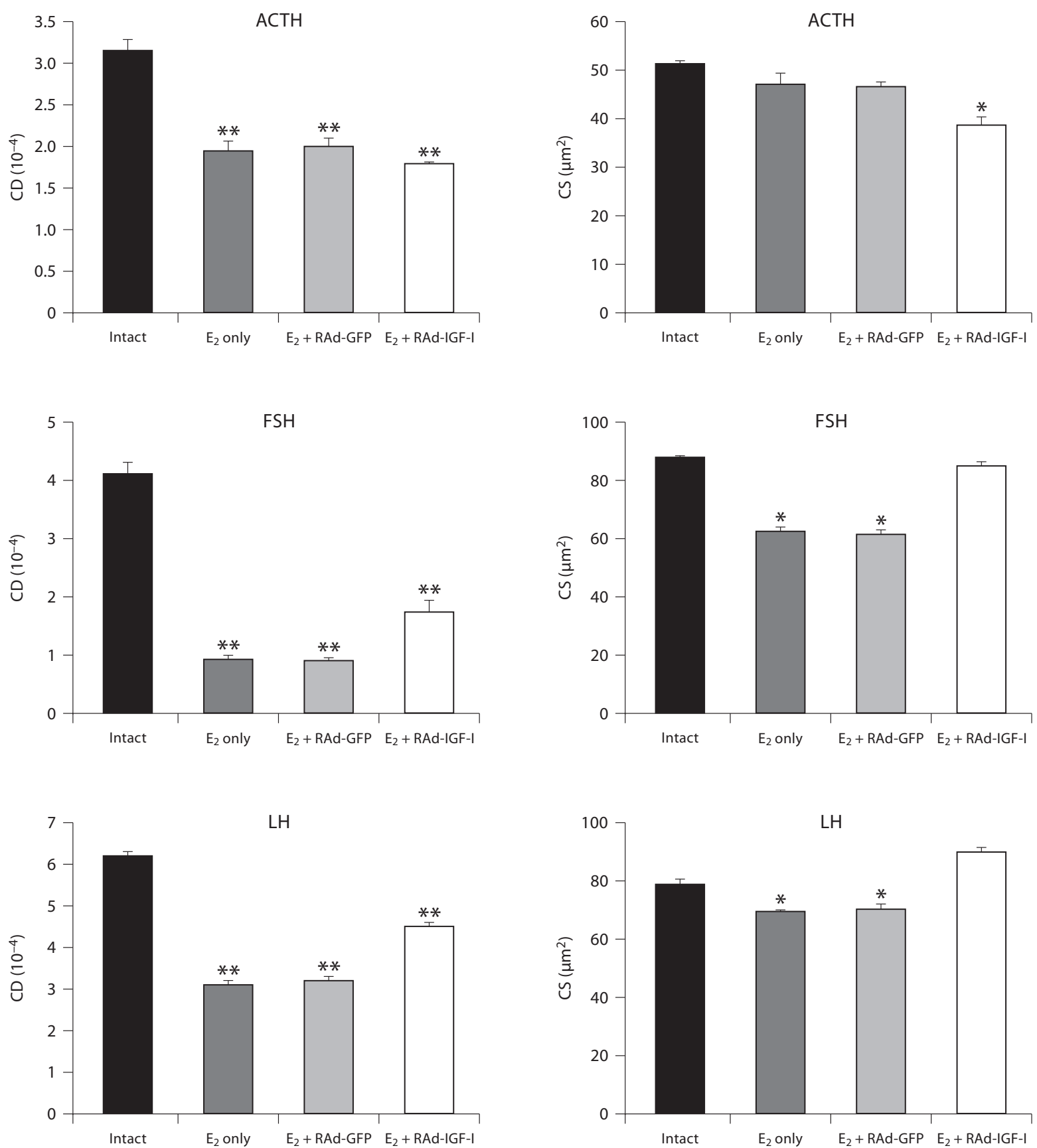

Fig. 4. Effect of IGF-I gene therapy on cell density (CD) and cell size (CS) of corticotropes (ACTH cells) and gonadotropes (FSH and LH cells) in the pituitaries of an intact animal and animals treated with estrogen only $\left(\mathrm{E}_{2}\right.$ only) or estrogen plus RAd-GFP ( $\left.\mathrm{E}_{2}+\mathrm{RAd}-\mathrm{GFP}\right)$ (control treatments) or IGF-I gene therapy ( $\mathrm{E}_{2}+\mathrm{RAd}-\mathrm{IGF}-$ I). Columns represent mean values and bars above columns represent SEM values. Five pituitaries per group were assessed. ${ }^{*} \mathrm{p}<0.05,{ }^{* *} \mathrm{p}<0.01$ compared to the intact group. 
Table 1. Effect of chronic estrogen and intrapituitary tumor IGFI gene therapy on serum PRL levels

\begin{tabular}{ccccc}
\hline Time point & Intact & $\mathrm{E}_{2}$ only & $\begin{array}{l}\mathrm{E}_{2}+ \\
\text { RAd-GFP }\end{array}$ & $\begin{array}{l}\mathrm{E}_{2}+ \\
\text { RAd-IGF-I }\end{array}$ \\
\hline-25 days & $90 \pm 14$ & $73 \pm 16$ & $76 \pm 24$ & $82 \pm 7$ \\
-15 days & $76 \pm 14$ & $80 \pm 13$ & $151 \pm 24$ & $78 \pm 15$ \\
-10 days & $88 \pm 20$ & $180 \pm 45^{*}$ & $197 \pm 22$ & $190 \pm 24$ \\
0 day & $59 \pm 18$ & $347 \pm 50^{*}$ & $189 \pm 58$ & $241 \pm 40$ \\
+7 days & $65 \pm 12$ & $308 \pm 60^{*}$ & $260 \pm 57$ & $138 \pm 22^{*}$ \\
\hline
\end{tabular}

Serum PRL (ng/ml) was measured in blood samples taken serially from experimental day -25 to experimental day +7 . The number of rats used was 5 for all groups. $E_{2}=$ Estrogen. ${ }^{*} \mathrm{p}<0.01$ (intact vs. $\mathrm{E}_{2}$ only and $\mathrm{E}_{2}+$ RAd-GFP vs. $\mathrm{E}_{2}+$ RAd-IGF-I).
Table 2. Effect of chronic estrogen and intrapituitary tumor IGFI gene therapy on serum GH levels

\begin{tabular}{ccccc}
\hline Time point & Intact & $\mathrm{E}_{2}$ only & $\begin{array}{l}\mathrm{E}_{2}+ \\
\text { RAd-GFP }\end{array}$ & $\begin{array}{l}\mathrm{E}_{2}+ \\
\text { RAd-IGF-I }\end{array}$ \\
\hline-25 days & $33 \pm 6$ & $55 \pm 4$ & $48 \pm 16$ & $49 \pm 5$ \\
-15 days & $43 \pm 9$ & $84 \pm 10^{*}$ & $93 \pm 12$ & $81 \pm 4$ \\
-10 days & $29 \pm 7$ & $93 \pm 21^{* *}$ & $116 \pm 13$ & $114 \pm 11$ \\
0 day & $42 \pm 5$ & $152 \pm 15^{* *}$ & $159 \pm 18$ & $156 \pm 9$ \\
+ days & $24 \pm 7$ & $141 \pm 14^{* *}$ & $140 \pm 10$ & $95 \pm 8^{*}$ \\
\hline
\end{tabular}

Serum GH (ng/ml) was measured in blood samples taken serially from experimental day -25 to experimental day +7 . The number of rats used was 5 for all groups. $\mathrm{E}_{2}=$ Estrogen. ${ }^{*} \mathrm{p}<0.05$, ${ }^{* *} \mathrm{p}<0.01$ (intact vs. $\mathrm{E}_{2}$ only and $\mathrm{E}_{2}+$ RAd-GFP vs. $\mathrm{E}_{2}+\mathrm{RAd}-$ IGF-I). satisfactory therapy is not yet available [Shimon and Melmed, 1998]. In this context, gene therapy appears to be a potentially useful alternative for the treatment of pituitary tumors. Early studies showed that a herpes simplex virus type 1-derived vector was highly effective in vivo for gene transfer in rat pituitary prolactinomas [Bolognani et al., 2001]. An adenoviral vector harboring the herpes simplex virus type 1 TK suicide gene under the control of the human cytomegalovirus promoter (RAd$\mathrm{TK}$ ) was used to transfer the TK gene to $\mathrm{GH}_{3}$ and $\mathrm{AtT}_{20}$ rodent pituitary tumor cells. Incubation of RAd-TKtreated $\mathrm{GH}_{3}$ and $\mathrm{AtT}_{20}$ cells with the prodrug ganciclovir (which becomes toxic after phosphorylation by viral TK) caused significant destruction of the cultures [Windeatt et al., 2000]. In the same study, estrogen/sulpiride-induced rat prolactinomas were stereotaxically injected with the same RAd-TK. Subsequent injection of the host animals with 2 daily intrapituitary doses of ganciclovir $(25 \mathrm{mg} / \mathrm{kg})$ for 7 days succeeded in partially reducing tumor size and serum PRL levels. Another type of gene therapy strategy for the treatment of pituitary cancer is that based on the transfer of a gene(s) with the ability to rescue the normal phenotype of tumor cells. This approach has been implemented in mice heterozygous for the retinoblastoma tumor suppressor gene $\left(R b^{+-}\right.$mice), which develop and succumb to characteristic pituitary intermediate-lobe melanotrope tumors [Hu et al., 1994].

Our own work reveals that trophic factor gene therapy may constitute a suitable alternative to suicide gene therapy for the treatment of pituitary adenomas. In the present study, we confirmed that IGF-I gene therapy in estrogen-induced pituitary tumors partially reduced the marked hyperprolactinemia of the animals and also tended to reverse phenotype changes in the lactotrope population [Cónsole et al., 2008]. The mechanism by which pituitary overexpression of IGF-I inhibits lactotropic cell growth and PRL secretion is not clear. Although estrogen is known to increase pituitary expression of IGF-I mRNA, it also increases the expression of IGF-binding protein 2 mRNA [Michels et al., 1993].

Our findings show that IGF-I gene therapy in estrogen-induced pituitary tumors is also beneficial for the somatotropic cell population. The fact that IGF-I administration did not restore the size of somatotropes reveals the importance of locally produced IGF-I, according to Stefaneanu et al. [1999]. Continuous subcutaneous administration of IGF-I (7-21 $\mu \mathrm{g} / \mathrm{kg} / \mathrm{h})$ demonstrated that with a decrease in the GH levels of greater than $50 \%$, IGF-I suppressed both the number of $\mathrm{GH}$ pulses and the GH mass secreted per pulse [Ray and Melmed, 1997]. In line with these results, our data show that intrapituitary RAd-IGFI administration lowers serum levels of GH. The IGF-I gene therapy approach described here in an experimental rat adenoma model appears to be effective to decrease the size of somatotropes and lower the circulating GH levels, probably by inhibiting $\mathrm{GH}$ secretion.

Daily administration of estradiol benzoate to intact male rats led to an increase in circulating TSH after 7 days of treatment, without alteration of the basal level or the TSH pituitary content [De Lean and Labrie, 1977]. Estradiol is an important mitogen for thyrocytes in rats, as it enhances the action of TSH and has an independent stimulatory effect on proliferation [Banu et al., 2002]. Our data also suggest that RAd-IGF-I tends to restore cell 
density, without changing cell size. The stimulatory effect of IGF-I in our prolactinomas is in line with reports in thyroid cells, where IGF-I has been found to potentiate TSH-induced proliferation in vitro [Kimura et al., 2001]. In the thyrocyte milieu, this stimulatory action of IGF-I may lead to a potentiation of TSH signaling [Kimura et al., 2001]. Moreover, Chandrashekar and Bartke [2003] speculated on the role of the IGF system in determining gender-related differences in thyroid disease.

In female rats, estradiol administration decreases the ACTH response to stress [Young et al., 2001]. These results are consistent with our results, which showed an inhibitory effect of estrogen on the corticotrope population. IGF-I seems to be produced constitutively in ACTH cells, possibly indicating its particular importance in the stress response. IGF-I from endocrine cells may control hormone synthesis and release in an autocrine-paracrine manner as well as prevent apoptosis and stimulate proliferation [Eppler et al. 2007]. In the present study, treatment with RAd-IGF-I induced a significant decrease in ACTH cell size without changes in the cell density compared to estrogen + Rad-GFP treatment. These data agree with the findings of Van Wijk et al. [1998], who reported that intrapituitary IGF-I does not have growth-stimulating effects on canine corticotropic tumor cells.

The biosynthesis and release of gonadotropin-releasing hormone $(\mathrm{GnRH})$ are under complex excitatory and inhibitory control by a number of paracrine factors, including IGF-I, which can modify GnRH synthesis and actions on gonadotropes [Chandrashekar and Bartke, 2003]. Tilemans et al. [1992] showed that the development of PRL-, GH- and ACTH-containing cells in the anterior pituitary of the rat is modulated by $\mathrm{GnRH}$ and that this action is mediated by specific growth factors released by gonadotropes.

Estrogen-induced changes in the pars distalis proteome may be associated with effects on gonadotropes related to negative feedback or associated with other pituitary cells [Blake et al., 2005]. Our data show that estrogen treatment had an inhibitory effect on the gonadotrope population, with a decrease in the cell size and cell density.

Incubation of pituitary cells from salmon with IGF-I for 7 or 10 days resulted in significantly higher FSH release and remaining cell content of FSH and LH [Baker et al., 2000], which indicates that the stimulatory effect of IGF-I on LH synthesis is exerted through a specific increase in the transcription level of the $\beta$ subunit in Atlantic salmon [Schmitz, 2004]. IGF-I has different effects on gonadotropins from human anterior pituitary adenomas, stimulating intact FSH, inhibiting or having no effect on intact $\mathrm{LH}$ in vitro and increasing both the viability and number of tumorous glycoprotein-secreting cells entering the S phase of proliferation [Atkin et al., 1993].

Estradiol and IGF-I may exert antiapoptotic effects and thus possibly control the size of gonadotropes [Melamed et al., 1999]. In our group of animals treated with estrogen + RAd-IGF-I, but not those treated with estrogen + Rad-GFP, this decrease in gonadotrope cell size and cell density was reversed, thus confirming the restorative effect of transgenic IGF-I on estrogen-induced pituitary tumors.

We conclude that IGF-I gene therapy has an overall beneficial effect on estrogen-induced pituitary tumors. It remains to be determined whether IGF-I may have similar beneficial effects on other types of pituitary adenomas. If so, IGF-I gene therapy might emerge as an effective adjuvant to conventional therapies (in particular, pituitary surgery) for the treatment of human pituitary tumors [Rodríguez et al., 2009].

\section{Acknowledgements}

The authors are indebted to Mrs. C. Ferese for the histological processing of pituitary specimens and to Ms. G. Simonetto for editorial assistance. This work was supported in part by grants 11/M121 of the National University of La Plata and CICPBA to G.M.C. and grant R01AG029798-2 to R.G.G. R.G.G. and G.M.C. are CONICET and CICPBA career researchers, respectively.
References
Atkin, S., A. Landolt, R. Jeffreys, L. Hipkin, J. Baker, D., B. Davies, W. Dickhoff, P. Swanson Radcliffe, C. Squire, M. White (1993) Differential effects of insulin-like growth factor I on the hormonal product and proliferation of glycoprotein-secreting human pituitary adenomas. J Clin Endocrinol Metab 77: 1059-1066.

Bach, M., C. Bondy (1992) Anatomy of the pituitary insulin-like growth factor system. Endocrinology 131: 2588-2594. (2000) Insulin-like growth factor I increases follicle-stimulating hormone (FSH) content and gonadotropin-releasing hormone-stimulated FSH release from coho salmon pituitary cells in vitro. Biol Reprod 63: 865-871.

- Banu, S., P. Govindarajulu, M. Aruldhas (2002) Testosterone and estradiol differentially regulate TSH-induced thyrocyte proliferation in immature and adult rats. Steroids 67: 573579 . 
Blake, C., L. Brown, M. Duncan, S. Hunsucker, S. Helmke (2005) Estrogen regulation of the rat anterior pituitary proteome. Exp Biol Med (Maywood) 230: 800-807.

-Bolognani, F., C. Albariño, V. Romanowski, N. G. Carri, R.G. Goya (2001) In vitro and in vivo herpetic vector-mediated gene transfer in the pituitary gland: impact on hormone secretion. Eur J Endocrinol 145: 497-503.

-Chandrashekar, V., A. Bartke (2003) The role of insulin-like growth factor-I in neuroendocrine function and the consequent effects on sexual maturation: inferences from animal models. Reprod Biol 3: 7-28.

Cónsole, G., C. Hereñú, G. Camihort, G. Luna, M. Bracamonte, G. Morel, R. Goya (2008) Insulin-like growth factor-I gene therapy reverses morphologic changes and reduces hyperprolactinemia in experimental rat prolactinomas. Mol Cancer 7: 13.

-Cónsole G., C. Hereñú, G. Camihort, G. Luna, C. Ferese, R. Goya (2009) Effect of insulinlike growth factor-I gene therapy on the somatotropic axis in experimental prolactinomas. Cells Tissues Organs 190: 20-26.

Cónsole, G., S. Jurado, M. Petruccelli, M. Carino, R. Calandra, C. Gómez Dumm (2002) Influence of photoinhibition on the morphology and function of pituitary lactotropes in male golden hamster. Neuroendocrinology 75: 316-325.

Cónsole, G., S. Jurado, S. Rulli, R. Calandra, C. Gómez Dumm (2001) Ultrastructural and quantitative immunohistochemical changes induced by nonsteroid antiandrogens on pituitary gonadotroph population of prepuberal male rats. Cells Tissues Organs 169: 64-72.

Daughaday, W.H., P. Rotwein (1989) Insulin-like growth factors I and II. Peptide, messenger ribonucleic acid and gene structures, serum, and tissue concentrations. Endocr Rev 10: 68-91.

De Lean, A., F. Labrie (1977) Sensitizing effect of treatment with estrogens on TSH response to TRH in male rats. Am J Physiol 233: E235E239.

D'Ercole, A.J., A.D. Stiles, L.E. Underwood (1984) Tissue concentrations of somatomedin C: further evidence for multiple sites of synthesis and paracrine or autocrine mechanisms of action. Proc Natl Acad Sci USA 81: 935-939.

Eppler, E., T. Jevdjovic, C. Maake, M. Reinecke (2007) Insulin-like growth factor I (IGF-I) and its receptor (IGF-1R) in the rat anterior pituitary. Eur J Neurosci 25: 191-200.

- Halper, J., P. Parnel, B. Carter, P. Ren, B. Scheithauer (1992) Presence of growth factors in human pituitary. Lab Invest 66: 639645.
Hána, V., M. Haluzik, V. Schreiber (1998) Independence of estrogen-induced pituitary proliferation on local IGF-I mRNA and EGF mRNA expression. Modifying effects of tamoxifen and terguride. Physiol Res 47: 125-131.

Hereñú, C.B., C. Cristina, O.J. Rimoldi, D. BecúVillalobos, V. Cambiaggi, E.L. Portiansky R.G. Goya (2007) Restorative effect of insulin-like growth factor-I gene therapy in the hypothalamus of senile rats with dopaminergic dysfunction. Gene Ther 14: 237-245.

Houben, H., C. Denef (1994) Bioactive peptides in anterior pituitary cells. Peptides 15: 547582 .

Hu, N., A. Gutsmann, D.C. Herbert, A. Bradley, W. H. Lee, E.Y. Lee (1994) Heterozygous Rb1 delta 20/+ mice are predisposed to tumors of the pituitary gland with a nearly complete penetrance. Oncogene 9: 1021-1029.

Ishida, M., W. Takahashi, S. Itoh, S. Shimodaira, S. Maeda, J. Arita (2007) Estrogen actions on lactotroph proliferation are independent of a paracrine interaction with other pituitary cell types: a study using lactotroph-enriched cells. Endocrinology 148: 3131-3139.

Kawashima, K., K. Yamakawa, W. Takahashi, S. Takizawa, P. Yin, N. Sugiyama, S. Kanba, J. Arita (2002) The estrogen-occupied estrogen receptor functions as a negative regulator to inhibit cell proliferation induced by insulin/IGF-1: a cell context-specific antimitogenic action of estradiol on rat lactotrophs in culture. Endocrinology 143: 2750-2758.

Kimura, T., A. Van Keymeulen, J. Golstein, A. Fusco, J. Dumont, P. Roger (2001) Regulation of thyroid cell proliferation by TSH and other factors: a critical evaluation of in vitro models. Endocr Rev 22: 631-656.

Lloyd, R.V. (1983) Estrogen-induced hyperplasia and neoplasia in the rat anterior pituitary gland. Am J Pathol 113: 198-206.

- Melamed, P., G. Gur, H. Rosenfeld, A. Elizur, Z. Yaron (1999) Possible interactions between gonadotrophs and somatotrophs in the pituitary of tilapia: apparent roles for insulin-like growth factor I and estradiol. Endocrinology 140: 1183-1191.

Michels, K.M., W.H. Lee, A. Seltzer, J.M. Saavedra, C.A. Bondy (1993) Up-regulation of pituitary [125I]insulin-like growth factor-I (IGF-I) binding and IGF binding protein-2 and IGF-I gene expression by estrogen. Endocrinology 132: 23-29.

- Okajima, K., N. Harada (2008) Promotion of insulin-like growth factor-I production by sensory neuron stimulation; molecular mechanism(s) and therapeutic implications. Curr Med Chem 15: 3095-3112.
Paxinos, G., C. Watson (1998) The Rat Brain in Stereotaxic Coordinates. San Diego, Academic Press.

Ray, D., S. Melmed (1997) Pituitary cytokine and growth factor expression and action. Endocr Rev 18: 206-228.

Rodríguez, S., M. Castro, O.A. Brown, R. Goya, G. Cónsole (2009) Gene therapy for the treatment of pituitary tumors (review). Expert Rev Endocrinol Metab 4: 359-370.

Sarkar, D.K., P.E. Gottschall, J.P. Meites (1982) Damage to hypothalamic dopaminergic neurons is associated with development of prolactin-secreting tumors. Science 218: 684-686.

-Schmitz, M. (2004) Differential effect of insulinlike growth factor I on in vitro gonadotropin subunits expression in Atlantic salmon. Fish Physiol Biochem 28: 105-106.

-Shimon, I., S. Melmed (1998) Management of pituitary tumors. Ann Intern Med 129: 472483

Shy, K.K., A.M. McTiernan, J.R. Daling, N.S. Weiss (1983) Oral contraceptive use and the occurrence of pituitary prolactinoma. JAMA 249: 2204-2207.

-Stefaneanu, L., L. Powell-Braxton, W. Won, V. Chandrashekar, A. Bartke (1999) Somatotroph and lactotroph changes in the adenohypophysis of mice with disrupted insulinlike growth factor I gene. Endocrinology 140: 3881-3889.

Tilemans, D., M. Andries, C. Denef (1992) Luteinizing hormone-releasing hormone and neuropeptide $\mathrm{Y}$ influence deoxyribonucleic acid replication in three anterior pituitary cell types. Evidence for mediation by growth factors released from gonadotrophs. Endocrinology 130: 882-894.

Van Wijk, P., A. Rijnberk, R. Croughs, B. Meij, J. Mol (1998) Effects of corticotrophin-releasing hormone, vasopressin and insulin-like growth factor-I on proliferation and adrenocorticotrophic hormone secretion by canine corticotrophic adenoma cells in vitro. Eur J Endocrinol 138: 309-315.

Webster, J., J. Ham, J. Bevan, M. Scalon (1989) Growth factors and pituitary tumors. Trends Endocrinol Metab 1: 85-98.

Windeatt, S., T.D. Southgate, R.A. Dewey, F. Bolognani, M.J. Perone, A.T. Larregina, T.C. Maleniak, I.D. Morris, R.G. Goya, D. Klatzmann, P.R. Lowenstein, M.G. Castro (2000) Adenovirus-mediated herpes simplex virus type- 1 thymidine kinase gene therapy suppresses oestrogen-induced pituitary prolactinomas. J Clin Endocrinol Metab 85: 1296-1305

-Young, E.A., M. Altemus, V. Parkison, S. Shastry (2001) Effects of estrogen antagonists and agonists on the ACTH response to restraint stress in female rats. Neuropsychopharmacology 25: 881-891. 